Vol. 52, z. (1-2) - 1999

$85-94$

\title{
Effect of the number of calcium chloride sprays on 'Jonagold' apple quality
}

\section{PAWEŁ WÓJCIK}

\begin{abstract}
Department of Fruit Crop Management and Plant Nutrition, Research Institute of Pomology and Floriculture, Pomologiczna 18, 96-100 Skierniewice, Poland
\end{abstract}

(Received: March 2, 1999)

\begin{abstract}
Sum mary
The aim of this study was to examine effect of frequency of calcium chloride $\left(\mathrm{CaCl}_{2}\right)$ sprays on 'Jonagold' apple (Malus domestica Borkh.) quality. The experiment was carried out in 1996-1998 in the Experimental Orchard of the Research Institute of Pomology and Floriculture in Skierniewice. Apple trees were grafted on M.26 rootstock and planted in 1992 at a distance of $4 \times 2$ m on a sandy loam soil with high available phosphorus, potassium and magnesium contents. Four experimental treatments were applied: (i) three sprays with $\mathrm{CaCl}_{2}$ solutions at 2, 10 and 18 weeks after full bloom, (ii) six sprays with $\mathrm{CaCl}_{2}$ at 2, 6, 10, 14, 16 and 18 weeks after full bloom, (iii) nine sprays with $\mathrm{CaCl}$ at $2,4,6,8,10,12,14,16$ and 18 weeks after full bloom and (iv) control plot - trees unsprayed with $\mathrm{CaCl}_{2}$.

The results showed that fruit $\mathrm{Ca}$ concentration increased with the number of $\mathrm{CaCl}_{2}$ sprays during the growing season. Apples nine-times sprayed with $\mathrm{CaCl}_{2}$, solutions were smaller, less mature at harvest and after storage, had lower titratable acidity and soluble solids contents after storage and were less sensitive to bitter pit, internal breakdown and Gloeosporium-rot compared to other treatments; however these effects were influenced by the growing season. Six $\mathrm{CaCl}_{2}$ sprays only in one year of the study increased fruit firmness after storage, fruit resistance to bitter pit and internal breakdown. Three $\mathrm{CaCl}_{2}$ sprays decreased bitter pit incidence; however this effect was found only in one investigated year.
\end{abstract}

Key words: 'Jonagold' apple trees, calcium sprays, fruit quality.

\section{INTRODUCTION}

Calcium (Ca) status plays an important role in apple quality (Marcelle, 1995). Low $\mathrm{Ca}$ concentrations in apple flesh tissues increase the risk of the incidence of diseases and physiological disorders and stimulate fruit softening during storage (Conway et al., 1992; Conway et al., 1995; Yuen, 1993). Calcium deficiency in apple flesh occurs even on the soils rich in Ca (Sadowski and Cąderek, 1967; Sadowski 
and Świderska, 1977; Vang-Petersen, 1980), which indicates that apple Ca content is related mainly to specific Ca movement within plants. In order to control apple $\mathrm{Ca}$ deficiency, preharvest sprays with $\mathrm{Ca}$ salts are recommended. In Poland, Sadowski et al. (1969) showed that three sprays with Ca salts were as effective in the reduction of 'Belle de Boskoop' apples with bitter pit as six and nine leaf applications; although it was found that more frequent sprays resulted in higher increase of fruit $\mathrm{Ca}$ concentration. However, Tomala (1997) thinks that under Polish conditions it should be applied 5-6 sprays with Ca solutions during the growing season to reach the high apple quality. According to Raese (1994) the optimal number of Ca sprays during the growing season depends on many environmental-, biological- and soil- conditions including: soil texture, potassium and magnesium contents in soil, soil moisture, tree vigour and natural sensitivity of apple fruit to physiological disorders, etc. Taking into consideration that sandy soils with high $\mathrm{K}$ levels predominate in orchards in Central Poland and the low amounts of rainfall occur during the growing season, it seems that the number of Ca sprays may be higher than currently recommended. It may be true particularly in the case of $\mathrm{cv}$. Jonagold which has natural low fruit $\mathrm{Ca}$ concentration. Therefore, the aim of this study was to investigate the effect of the frequency of Ca sprays during the growing season on 'Jonagold' apple quality.

\section{MATERIALS AND METHODS}

The study was conducted in 1996-1998 in the Experimental Orchard of the Research Institute of Pomology and Floriculture in Skierniewice on 'Jonagold' apple trees (Malus domestica Borkh.) grafted on M.26 rootstock. The trees were planted in autumn 1992 at a distance of $4 \times 2 \mathrm{~m}$ on a sandy loam soil with organic matter content $14 \mathrm{~g} \mathrm{~kg}^{-1}$, $\mathrm{pH}_{(\mathrm{KCl})} 5.9$, available phosphorus (P) $69 \mathrm{mg} \mathrm{kg}^{-1}$, potassium (K) $145 \mathrm{mg} \mathrm{kg}^{-1}$ and magnesium $(\mathrm{Mg}) 65 \mathrm{mg} \mathrm{kg}^{-1}$. Soil organic matter content was determined according to Tiurin's method, P and K Egner-Riehm's method and Mg Schachtschabel's method. In the third year after planting the interrows were grassed down whereas the herbicide strips were kept along the rows. The trees were trained as a spindle. Because of the high contents of available $\mathrm{P}, \mathrm{K}$ and $\mathrm{Mg}$ in the soil, those nutrients were not applied during the experiment. Every year, nitrogen (as ammonium nitrate) was applied at a rate of 60 $\mathrm{kg} \mathrm{ha}^{-1}$, uniformly over the surface of the herbicide strips at a width of $1.5 \mathrm{~m}$, just before the bud break. The experiment was set up using a randomised complete block design with three replicates. Each experimental plot consisted of ten trees. There were two trees between plots as protective belts. Four experimental treatments were applied:

(i) three sprays with $\mathrm{CaCl}_{2}$ at 2,10 and 18 weeks after full bloom at the rates of 3,5 and $7 \mathrm{~kg} \mathrm{ha}^{-1}$, respectively.

(ii) six sprays with $\mathrm{CaCl}_{2}$ at 2, 6, 10,14,16 and 18 weeks after full bloom at the rates of $3,4,5,6,7$ and $7 \mathrm{~kg}$ ha- 1 , respectively.

(iii) nine sprays with $\mathrm{CaCl}_{2}$ at $2,4,6,8,10,12,14,16$ and 18 weeks after full bloom at the rates of $3,3,4,4,5,5,6,6,7$ and $7 \mathrm{~kg} \mathrm{ha}^{-1}$, respectively.

(iv) control plot - trees unsprayed with $\mathrm{CaCl}_{2}$.

Sprays with $\mathrm{CaCl}_{2}$ solutions were done in the morning when the leaves were dry using SEPIA sprayer with directed air-stream at a volume of $1000 \mathrm{~L}$ of water. 
The following measurements and observations were carried out during the experiment:

1. Mean fruit weight was calculated based on a $15-\mathrm{kg}$ bulk apple sample from each plot.

2. Streif's index [F/(RS)] of fruit at harvest (15, 19 and 16 October in 1996, 1997 and 1998 , respectively) was estimated according to following the formula:

$\mathrm{F} /(\mathrm{RS})=$ Firmness $[\mathrm{kg}] /($ soluble solids content $[\%] \times$ starch index).

Fruit firmness was measured on 20 apples from each plot using a Magness-Taylor's firmness-tester, with a 11-mm tip which penetrated to a depth of $8 \mathrm{~mm}$. Mean firmness from measurements on the blush and opposite side of each apple were calculated.

Starch index was estimated on 20 apples from each plot by iodine test using a scale ranged from 1 ( $100 \%$ of hue of cross section area) to 10 ( $0 \%$ of hue).

Soluble solids content (SSC) was determined in the juice squeezed out of the homogenate of 20 apples from each plot using Abbe's refractometer.

3. Titratable acidity (TA) of fruit at harvest was determined in homogenate of 20 apples from each plot by titrating the solution to $\mathrm{pH} 8.1$ with $0.1 \mathrm{M} \mathrm{NaOH}$. The data were calculated into malic acid.

4. Nitrogen, $\mathrm{P}, \mathrm{K}, \mathrm{Mg}$ and $\mathrm{Ca}$ concentrations in apple flesh were determined immediately after fruit harvest. Three fruits from each tree at a diameter of $8.0-8.5 \mathrm{~cm}$ were sampled. Seeds and stem from each apple were removed and then 2 quarters of fruit were cut out from two opposite sides. The fruit samples were dried at $75^{\circ} \mathrm{C}$ for $72 \mathrm{~h}$ and ground to pass a 40-mesh screen. Nitrogen was determined according to Kjeldahl's method. In order to determine $\mathrm{P}, \mathrm{K}, \mathrm{Ca}$ and $\mathrm{Mg}$, the fruit samples were digested in 9:1 (v/v) diacid mixture of $\mathrm{HNO}_{3}$ and $\mathrm{HClO}_{4}$. Potassium, $\mathrm{Mg}$ and $\mathrm{Ca}$ were determined by atomic absorption spectrophotometry and $\mathrm{P}$ colorimetrically by the vanado-molybdo-phosphoric method. The concentrations of nutrients were expressed in relation to dry matter (DM).

5. Leaf $\mathrm{Ca}$ concentration was determined in the identical way as in the case of fruit tissue $\mathrm{Ca}$ content. Five leaves from each tree were collected at fruit harvest from the middle part of current shoots. Leaf samples after collecting were washed in distilled water.

6. Firmness, TA and SSC of apples after storage were estimated based on a 25 -fruit sample from each plot. Apples were stored for 100 days in refrigerated air storage at $1-2^{\circ} \mathrm{C}$ and a relative air humidity of $88-90 \%$. These measurements were done 7 days after removing fruit samples from storage to simulate normal ripening.

7. Incidence of physiological disorders and diseases after storage were calculated on a $20-\mathrm{kg}$ bulk fruit sample from each plot.

Analysis of variance was conducted on all data. Differences between mean treatment values were evaluated separately for each season by Duncan's multiple range test at the level of significance $\mathrm{P} \leq 0.05$. Data of the occurrence of physiological disorders and diseases were transformed according to the Bliss's formula. 


\section{RESULTS}

Nine Ca sprays decreased mean fruit weight compared to those of control plots; although in last year of the study (1998) this effect was not observed (Table 1). Threeand six-times $\mathrm{Ca}$ applications had no effect on fruit weight.

In all investigated years nine Ca sprays increased Streif's index values of 'Jonagold' apples compared to those of control plot whereas three- and six-times $\mathrm{Ca}$ applications had no effect on this parameter (Table 1).

Table 1

Effect of the number of calcium chloride sprays on 'Jonagold' apple quality at harvest

\begin{tabular}{|l|c|c|c|c|c|c|c|c|c|}
\hline \multirow{2}{*}{ Treatment } & \multicolumn{3}{|c|}{$\begin{array}{c}\text { Mean fruit weight } \\
{[\mathrm{g}]}\end{array}$} & \multicolumn{3}{c|}{ Streif's index } & \multicolumn{3}{c|}{$\begin{array}{c}\text { Titratable acidity } \\
\text { [mg 100g }\end{array}$} \\
\cline { 2 - 10 } & \multicolumn{3}{|c|}{ FM] } \\
\cline { 2 - 10 } & 1996 & 1997 & 1998 & 1996 & 1997 & 1998 & 1996 & 1997 & 1998 \\
\hline Three Ca sprays & $184.9 \mathrm{~b}$ & $170.3 \mathrm{~b}$ & $171.0 \mathrm{a}$ & $0.094 \mathrm{a}$ & $0.100 \mathrm{a}$ & $0.086 \mathrm{a}$ & $523 \mathrm{~b}$ & $490 \mathrm{~b}$ & $520 \mathrm{a}$ \\
Six Ca sprays & $183.0 \mathrm{~b}$ & $169.3 \mathrm{~b}$ & $169.3 \mathrm{a}$ & $0.100 \mathrm{a}$ & $0.096 \mathrm{a}$ & $0.090 \mathrm{a}$ & $500 \mathrm{~b}$ & $507 \mathrm{~b}$ & $504 \mathrm{a}$ \\
Nine Ca sprays & $169.3 \mathrm{a}$ & $159.7 \mathrm{a}$ & $169.3 \mathrm{a}$ & $0.117 \mathrm{~b}$ & $0.123 \mathrm{~b}$ & $0.103 \mathrm{~b}$ & $423 \mathrm{a}$ & $418 \mathrm{a}$ & $508 \mathrm{a}$ \\
Control & $185.0 \mathrm{~b}$ & $171.7 \mathrm{~b}$ & $169.8 \mathrm{a}$ & $0.097 \mathrm{a}$ & $0.099 \mathrm{a}$ & $0.091 \mathrm{a}$ & $527 \mathrm{~b}$ & $487 \mathrm{~b}$ & $507 \mathrm{a}$ \\
\hline
\end{tabular}

Means values within column marked with the same letters do not differ significantly at $\mathrm{P}=0.05$

Titratable acidity of 'Jonagold' apples at harvest was influenced by the number of leaf $\mathrm{Ca}$ applications and the growing season (Table 1). Namely, nine Ca sprays significantly decreased TA of fruit compared to those of control plots; however this effect was not observed in the last year of the study (1998).

Fruit $\mathrm{Ca}$ concentrations from control plots were relatively low and ranged from 169 to $201 \mathrm{mg} \mathrm{Ca} \mathrm{kg}^{-1} \mathrm{DM}$. Calcium concentration in apple flesh tissues increased with frequency of Ca sprays during the growing season (Table 2). Three-, six- and ninetimes $\mathrm{Ca}$ applications increased apple $\mathrm{Ca}$ concentrations by 28,56 and $81 \%$, respectively. $\mathrm{K} / \mathrm{Ca}$ ratios in the control fruit were relatively high and ranged from 52 to 54 . It was found that $\mathrm{K} / \mathrm{Ca}$ ratio in fruit was influenced by frequency of Ca sprays. Namely, $\mathrm{K} / \mathrm{Ca}$ ratio in fruit decreased with the number of $\mathrm{Ca}$ applications (Table 2). Calcium sprays had no effect on concentrations of $\mathrm{N}, \mathrm{P}, \mathrm{K}$ and $\mathrm{Mg}$ in fruit and averaged: $0.18 \mathrm{~g}$

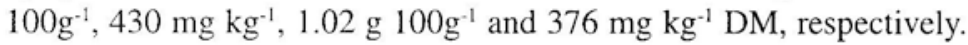

Generally, leaf $\mathrm{Ca}$ concentration was affected by the number of Ca sprays during the growing season. The highest leaf $\mathrm{Ca}$ concentration was found as a result of nine $\mathrm{Ca}$ sprays (Table 2). Also, six-times Ca applications increased leaf Ca concentration compared to those of control plots; although this treatment was less effective than ninetimes $\mathrm{Ca}$ applications. No significant differences in leaf $\mathrm{Ca}$ concentration was found between three $\mathrm{Ca}$ sprays and control plots.

In all years 'Jonagold' apple nine-times Ca sprayed had the higher firmness after storage compared to those of control plots (Table 3). Only in the last year of the experiment (1998) fruit six-times Ca sprayed were firmer than control ones. 
Table 2

Effect of the number of calcium chloride sprays of 'Jonagold' apple trees on Ca concentration and $\mathrm{K} / \mathrm{Ca}$ ratio in fruit and leaf $\mathrm{Ca}$ concentration

\begin{tabular}{|c|c|c|c|c|c|c|c|c|c|}
\hline \multirow[t]{2}{*}{ Treatment } & \multicolumn{3}{|c|}{$\begin{array}{l}\text { Fruit Ca concentration } \\
\qquad\left[\mathrm{mg} \mathrm{kg}^{-1} \mathrm{DM}\right]\end{array}$} & \multicolumn{3}{|c|}{$\mathrm{K} / \mathrm{Ca}$ ratio } & \multicolumn{3}{|c|}{$\begin{array}{c}\text { Leaf Ca concentration } \\
\qquad\left[\mathrm{g} 100 \mathrm{~g}^{-1}\right]\end{array}$} \\
\hline & 1996 & 1997 & 1998 & 1996 & 1997 & 1998 & 1996 & 1997 & 1998 \\
\hline Three Ca sprays & $241 b$ & $221 \mathrm{~b}$ & $237 b$ & $42.3 \mathrm{c}$ & $44.3 c$ & $43.0 \mathrm{c}$ & $1.59 \mathrm{a}$ & $1.51 \mathrm{a}$ & $1.81 \mathrm{a}$ \\
\hline Six Ca sprays & $294 \mathrm{c}$ & $273 \mathrm{c}$ & $285 \mathrm{c}$ & $35.0 \mathrm{~b}$ & $34.3 b$ & $34.3 b$ & $2.02 b$ & $1.93 \mathrm{~b}$ & $2.03 \mathrm{~b}$ \\
\hline Nine Ca sprays & $331 \mathrm{~d}$ & $306 \mathrm{~d}$ & $355 \mathrm{~d}$ & $29.7 \mathrm{a}$ & $29.7 \mathrm{a}$ & $26.0 \mathrm{a}$ & $2.59 \mathrm{c}$ & $2.60 \mathrm{c}$ & $2.31 \mathrm{c}$ \\
\hline Control & $178 \mathrm{a}$ & $169 \mathrm{a}$ & $201 \mathrm{a}$ & $54.0 \mathrm{~d}$ & $53.0 \mathrm{~d}$ & $52.0 \mathrm{~d}$ & $1.54 \mathrm{a}$ & $1.43 \mathrm{a}$ & $1.76 \mathrm{a}$ \\
\hline
\end{tabular}

Means values within column marked with the same letters do not differ significantly at $\mathrm{P}=0.05$

Table 3

Effect of the number of calcium chloride sprays of 'Jonagold' apple quality after storage

\begin{tabular}{|l|c|c|c|c|c|c|c|c|c|}
\hline \multirow{2}{*}{ Treatment } & \multicolumn{3}{|c|}{$\begin{array}{c}\text { Fruit firmness } \\
{[\mathrm{kg}]}\end{array}$} & \multicolumn{3}{c|}{$\begin{array}{c}\text { Titratable acidity } \\
{\left[\mathrm{mg} 100 \mathrm{~g}^{-1} \mathrm{FM}\right]}\end{array}$} & \multicolumn{3}{c|}{$\begin{array}{c}\text { Soluble solids content } \\
{[\%]}\end{array}$} \\
\cline { 2 - 10 } & 1996 & 1997 & 1998 & 1996 & 1997 & 1998 & 1996 & 1997 & 1998 \\
\hline Three Ca sprays & $4.2 \mathrm{a}$ & $4.3 \mathrm{a}$ & $4.4 \mathrm{a}$ & $323 \mathrm{~b}$ & $307 \mathrm{~b}$ & $297 \mathrm{a}$ & $12.5 \mathrm{~b}$ & $12.7 \mathrm{~b}$ & $12.9 \mathrm{a}$ \\
Six Ca sprays & $4.4 \mathrm{a}$ & $4.4 \mathrm{a}$ & $4.9 \mathrm{~b}$ & $310 \mathrm{~b}$ & $320 \mathrm{~b}$ & $310 \mathrm{a}$ & $12.8 \mathrm{~b}$ & $12.8 \mathrm{~b}$ & $12.6 \mathrm{a}$ \\
Nine Ca sprays & $5.0 \mathrm{~b}$ & $5.1 \mathrm{~b}$ & $5.0 \mathrm{~b}$ & $253 \mathrm{a}$ & $253 \mathrm{a}$ & $300 \mathrm{a}$ & $11.6 \mathrm{a}$ & $11.7 \mathrm{a}$ & $12.7 \mathrm{a}$ \\
Control & $4.4 \mathrm{a}$ & $4.3 \mathrm{a}$ & $4.2 \mathrm{a}$ & $323 \mathrm{~b}$ & $323 \mathrm{~b}$ & $300 \mathrm{a}$ & $12.8 \mathrm{~b}$ & $12.7 \mathrm{~b}$ & $12.5 \mathrm{a}$ \\
\hline
\end{tabular}

Means values within column marked with the same letters do not differ significantly at $\mathrm{P}=0.05$

Nine-times Ca applications decreased SSC and TA of 'Jonagold' apples after storage compared to those of control plots; however this effect was not observed in 1998 (Table 3).

Two physiological disorders occurred during the fruit storage: bitter pit and internal breakdown. Incidence of those disorders was affected by the number of Ca sprays and the growing season. In all years of the study nine Ca sprays were as effective in reducing bitter pit incidence as six Ca applications (Table 4). Only in 1998 three Ca sprays decreased the occurrence of affected apples by bitter pit; however this effect was less effective than six- and nine-times Ca applications. In the case of internal breakdown, nine Ca sprays decreased the incidence of 'Jonagold' apples with this disorder (Table 4). In the last year of the study (1998), six-times Ca applications also decreased apple sensitivity to internal breakdown but efficiency of this treatment was lower than nine Ca sprays. 
Table 4

Effect of the number of calcium chloride sprays on the incidence of 'Jonagold' apples with bitter pit, internal breakdown adn Gloeosporium-rot.

\begin{tabular}{|l|c|c|c|c|c|c|c|c|c|}
\hline \multirow{2}{*}{ Treatment } & \multicolumn{3}{|c|}{$\begin{array}{c}\text { Bitter pit } \\
{[\%]}\end{array}$} & \multicolumn{3}{c|}{$\begin{array}{c}\text { Internal breakdown } \\
\text { [\%] }\end{array}$} & \multicolumn{3}{c|}{$\begin{array}{c}\text { Percentage of apples with } \\
\text { Gloeosporium-rot }\end{array}$} \\
\cline { 2 - 11 } & 1996 & 1997 & 1998 & 1996 & 1997 & 1998 & 1996 & 1997 & 1998 \\
\hline Three Ca sprays & $11.9 \mathrm{~b}$ & $11.1 \mathrm{~b}$ & $6.7 \mathrm{~b}$ & $5.5 \mathrm{~b}$ & $6.7 \mathrm{~b}$ & $6.7 \mathrm{~b}$ & $4.3 \mathrm{~b}$ & $2.5 \mathrm{~b}$ & $2.8 \mathrm{~b}$ \\
Six Ca sprays & $3.9 \mathrm{a}$ & $7.0 \mathrm{a}$ & $2.6 \mathrm{a}$ & $5.7 \mathrm{~b}$ & $7.1 \mathrm{~b}$ & $2.7 \mathrm{a}$ & $3.2 \mathrm{~b}$ & $3.6 \mathrm{~b}$ & $3.3 \mathrm{~b}$ \\
Nine Ca sprays & $5.2 \mathrm{a}$ & $5.6 \mathrm{a}$ & $3.4 \mathrm{a}$ & $2.4 \mathrm{a}$ & $3.3 \mathrm{a}$ & $2.7 \mathrm{a}$ & $0.9 \mathrm{a}$ & $0.9 \mathrm{a}$ & $0.7 \mathrm{a}$ \\
Control & $12.5 \mathrm{~b}$ & $13.7 \mathrm{~b}$ & $13.6 \mathrm{c}$ & $5.6 \mathrm{~b}$ & $7.4 \mathrm{~b}$ & $6.0 \mathrm{~b}$ & $3.2 \mathrm{~b}$ & $3.2 \mathrm{~b}$ & $2.4 \mathrm{~b}$ \\
\hline
\end{tabular}

Means values within column marked with the same letters do not differ significantly at $\mathrm{P}=0.05$

In all years of the study nine Ca sprays decreased incidence of apples infected by Gloeosporium-rot after storage compared to those of control plots whereas other $\mathrm{Ca}$ treatments had not effect on apple resistance to this pathogen (Table 4). There was no significant differences in the number of apples infected by Penicillium sp., Monilinia sp. and Botrytis cinerea between Ca treatments and control plots (data not shown).

\section{DISCUSSION}

The results of this study showed that in two of three years nine Ca sprays decreased fruit weight . However, the reason of this phenomenon was not related to leaf damage. Possibly, that this effect was due to excess Ca concentration in leaf guard cells which induced periodical stomatal closure as shown by McAinsh at al. (1990). Also, Świetlik et al. (1982) and Świetlik et al. (1984) found that Ca sprays of 'York Imperial' apple seedlings decreased net photosynthesis and stomatal conductance in the leaves. Excess $\mathrm{Ca}$ concentrations in the leaves as factor decreasing fruit weight seems to be true because in 1998 when nine Ca sprays had not effect on fruit weight,

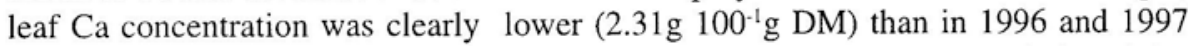

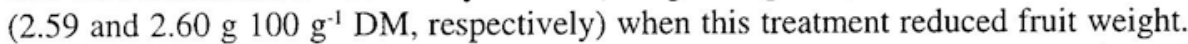
Taking into consideration that $\mathrm{Ca}$ concentration in leaves regulates mechanism of stomatal closing, it can be stated that 'Jonagold' leaf Ca concentration above $2.59 \mathrm{~g}$ $100 \mathrm{~g}^{-1}$ decreases stomatal conductance in the leaves. Thus, the decrease of TA and SSC in apples after storage as a result of nine-times $\mathrm{Ca}$ applications could be caused the reduction of leaf photosynthesis rate.

Streif's index has been commonly used indicator to estimate apple maturity status at harvest (Skrzyński, 1994). The higher Streif's index values of 'Jonagold' apples as a result of nine Ca sprays indicates that they were less mature at harvest than control fruit. Probably, the reason of this phenomenon was related to the increase of fruit flesh $\mathrm{Ca}$ concentration to level reducing maturity processes. It is possible because it is well proved that apples with high $\mathrm{Ca}$ concentrations produced less ethylene which is responsible for induction of the ripening processes (Burg and Burg, 1962 and Watkins et al., 1982). A lack of influence of three and six Ca sprays on 'Jonagold' apple maturity status at harvest indicates that not always higher $\mathrm{Ca}$ concentrations in apples lead to slowing their maturity processes. 
Fruit firmness is believed to be successful to determine status of fruit ripening (Poovaiah et al., 1988; Stow, 1993; Ben, 1997). In the present study it was found that 'Jonagold' apples nine-times Ca sprayed were firmer after storage compared to those of control ones which indicates that they were less mature. Probably, the reduction of ripening and fruit senescence as a result of nine Ca sprays resulted from the increase of Ca concentration in fruit flesh as shown by Faust and Shear (1972), Hulme and Rhodes (1971), Lougheed et al. (1979) and Sams and Conway (1984).

Low Ca concentration and/or high $\mathrm{K} / \mathrm{Ca}$ ratio in apple flesh is the reason for bitter pit development (Ferguson and Watkins, 1989). In the present study incidence of bitter pit in the control 'Jonagold' apples was relatively high (on average 13\%) which corresponded with the low $\mathrm{Ca}$ concentration and the high $\mathrm{K} / \mathrm{Ca}$ ratio in apple flesh (183 $\mathrm{mg} \mathrm{kg}^{-1} \mathrm{DM}$ and 53, respectively). Low Ca concentration in fruit was noted even in last two years of the study when amounts of precipitation were relatively high (711 and $779 \mathrm{~mm}$ in 1997 and 1998, respectively). Thus, it seems that apple Ca concentration is related more to specific distribution of $\mathrm{Ca}$ within apple trees than soil moisture. $\mathrm{Six}$ - and nine-times $\mathrm{Ca}$ applications had similar effect on the reduction of affected fruit by bitter pit despite that those treatments had different efficiency in increasing fruit $\mathrm{Ca}$ concentrations. Also, in two of three years of the experiment (1996 and 1997) three Ca sprays had not effect on sensitivity of apples to bitter pit in spite of the increase of fruit $\mathrm{Ca}$ concentration. It indicates that apple Ca concentration is not only factor influencing bitter pit development. Also, Saure (1996) thinks that incidence of bitter pit in apples is related to many pre- and postharvest factors, such as: climate, relationship between vegetative and generative growth, level of gibberellin within plant, fruit storage conditions, etc.

Internal breakdown is physiological disorder associated with senescence of fruit flesh tissues. Many studies showed that pre- and postharvest $\mathrm{Ca}$ applications decreased apple sensitivity to internal breakdown (Bangerth et al., 1972; Johnson et al., 1987; Lurie and Klein, 1992; Martin et al., 1975) which resulted from inhibiting fruit ripening processes. The present results confirmed the view that leaf $\mathrm{Ca}$ application can reduce the incidence of apple internal breakdown; although efficiency of this treatment was related to the frequency of Ca sprays in the growing season. Generally, nine Ca sprays enhanced 'Jonagold' apple resistance to internal breakdown which corresponded with the higher fruit firmness after storage. Also, in the last year (1998) apples six-times $\mathrm{Ca}$ sprayed were both firmer and less sensitive to internal breakdown. These results suggest that fruit firmness during storage may be good indicator to determine 'Jonagold' apple sensitivity to internal breakdown. It is worth noting that three $\mathrm{Ca}$ sprays had not effect on the incidence of apples damaged by internal breakdown despite that this treatment increased fruit $\mathrm{Ca}$ concentration. It indicates that development of this disorder was not closely related to fruit flesh Ca level.

The obtained results are in agreement with the study of Sharples and Johnson (1977) who found that postharvest apples losses due to Gloeosporium-rot were lower as a result of Ca sprays during the growing season. According to these authors lower apple sensitivity to Gloeosporium-rot infection as a result of leaf $\mathrm{Ca}$ applications resulted from stabilising the cell wall and maintaining fruit firmness. The present results confirm this hypothesis because 'Jonagold' apples nine-times Ca sprayed were both firmer and more resistant to infection of Gloeosporium-rot. 


\section{CONCLUSION}

1. Efficiency of $\mathrm{CaCl}_{2}$ sprays in improving 'Jonagold' apple fruit quality was related to the frequency of applied treatment in the growing season.

2. Fruit $\mathrm{Ca}$ concentration increased generally with the number of leaf $\mathrm{Ca}$ applications.

3. Apples nine-times sprayed with $\mathrm{CaCl}_{2}$ solutions were smaller, less mature at harvest and after storage, had lower titratable acidity and soluble solids contents after storage and were less sensitive to bitter pit, internal breakdown and Gloeosporiumrot; however these effects were influenced by the growing season.

4. Six $\mathrm{CaCl}_{2}$ sprays only in one year of the study increased fruit firmness after storage, fruit resistance to bitter pit and internal breakdown.

5. Three $\mathrm{CaCl}_{2}$ sprays decreased bitter pit incidence; however this effect was found only in one investigated year.

6. To minimise bitter pit incidence and prolong period of 'Jonagold' apple storage it should be applied 6-9 Ca sprays during the growing season for plants grown on sandy loam soil with high available $\mathrm{K}$ content.

\section{REFERENCES}

Bangerth F., Dilley D.R., Dewey D.H., 1972. Effect of postharvest calcium treatments on internal breakdown and respiration of apple fruits. J. Amer. Soc. Hort. Sci. 97: 679682.

B e n J., 1997. Określenie optymalnego terminu zbioru jabłek oraz warunki przechowywania nowych odmian w chłodniach. Konferencja Sadownicza „Uzyskanie jabłek najwyższej jakości", Brzezna: 20-24.

Burg S.P., Burg E.A. 1962. Role of ethylene in fruit ripening. Plant Physiol. 37: 179-187.

Conway W.S., Sams R.G., Hickey K.D. 1995. Commercial potential for increasing apple tissue calcium sufficiently to maintain fruit quality in storage. Postharvest Physiology, Pathology and Technology for Horticulture. Commodities, Agadir, Marocco: 70-74.

Conway W.S., Sams R.G., McGuire R.G., Kelman A.,1992. Calcium treatment of apples and potatoes to reduce postharvest decay. Plant Disease 76: 329-334.

Hulme A.C., Rhodes M.J.C. 1971. Pome fruits. In: The Biochemistry of Fruits and their Products. (A.C. Hulme, ed). Academic Press, London, England: 333-373.

Johnson D.S., Marks M.J., Pearson K. 1987. Storage quality of Cox's Orange Pippin apples in relation to fruit mineral composition during development. J.Hort. Sci. 62: 17-25.

Faust M., Shear C.B. 1972. The effect of calcium on respiration of apples. J. Amer. Soc. Hort. Sci. 97: 437-439.

Ferguson I.B., Watkins C.B. 1989. Bitter pit in apple fruit. Hort. Rev. 11: 289-355.

Lougheed E.C., Murr D.P., Miller S. R. 1979. Effect of calcium and daminozide on ethylene production and softening of apple fruits. Experientia 35: 43-44.

Lurie S., Klein J.D. 1992. Calcium and heat treatments to improve storability of Anna apples. HortScience 27: 36-39.

Marcelle R.D. 1995. Mineral nutrition and fruit quality. Acta Horticulturae 383: 219-226.

Martin D., Lewis T.L., Cerny J., Ratkowsky D.A. 1975. The predominant role of calcium as an indicator in storage disorders in Cleopatra apples. J. Hort. Sci. 50: 447-455.

McAinsh M.R., Brownlee C., Hetherington A.M. 1990. Abscisic acid-induced elevation of guard cell cytosolic $\mathrm{Ca}^{2+}$ precedes stomatal closure. Nature 343: 186-188.

Poovaiah B.W., Glenn G.M., Reddy A.S.N. 1988. Calcium and fruit softening. Physiology and biochemistry. Hort. Rev. 10: 107-152.

Raese J.T. 1994. Preharvest calcium use and effect on apples and pears. In: Tree Fruit Nutrition. (A.B. Peterson and R.G. Stevens, eds). Good Fruit Grower, Washington, pp: 109-122.

Sadowski A., Ambroziak E., Zielińska A. 1969. Studia nad gorzką plamistością podskórną jablek. IV. Dalsze badania nad wpływem nawożenia pozakorzeniowego. Zeszyty Naukowe SGGW, Warszawa 5: 203-231. 
Sadowski A., Cąderek T. 1967. Wstępne wyniki obserwacji nad występowaniem gorzkiej plamistości podskórnej na jabłkach odmiany Piękna z Boskoop, pochodzących z różnych warunków glebowo-klimatycznych. Roczniki Zakładu Studiów CSO, Warszawa: 3: 46-49.

S adowski A., Świderska S. 1977. Studies on bitter pit of apples. VII. Effect of calcium fertilization applied to the soil. Zeszyty Naukowe SGGW, Warszawa. 10: 105-117.

S a m s C.E , C onway W.S. 1984. Effect of calcium infiltration on ethylene production, respiration rate, soluble polyuronide content and quality of 'Golden Delicious' apple fruit. J. Amer. Soc. Hort. Sci. 109: 53-57.

S a u re M.C. 1996. Reassessment of the role of calcium in development of bitter pit in apple. Austral. J. Plant Physiol. 23: 237-243.

Sharples R.O., Johnson D.S. 1977. The influence of calcium on senescence changes in apple. Ann. Applied Biol. 85: 450-453.

Skrzyński J. 1994. Możliwości określania optymalnego terminu zbioru jabłek. Nowe Technologie w Przechowalnictwie Owoców, Skierniewice: 12-21.

S tow J. 1993. Effect of calcium ions on apple fruit softening during storage and ripening. Postharvest Biol. Techn. 3: 1-9.

Świetlik D., Bunce J.A., Miller S.S. 1984. Effect of foliar application of mineral nutrients on stomatal aperture and photosynthesis in apple seedling. J. Amer. Soc.Hort. Sci. 109: 306-312.

Świetlik D., Faust M., Korcak R.F. 1982. Effect of mineral nutrient sprays on photosynthesis and stomatal opening of water-stressed and unstressed apple seedlings. J. Amer. Soc. Hort. Sci. 107: 563-567.

Tomala K. 1997. Choroby fizjologiczne jabłek oraz metody zapobiegania. Konferencja Sadownicza „Uzyskanie jabłek najwyższej jakości”, Brzezna: 12-19.

Watkins C.B., Harman J.E., Ferguson I.B., Reid M.S. 1982. The action of lecithin and calcium dips in the control of bitter pit in apple fruit. J. Amer. Soc. Hort. Sci. 107: 262-265.

Vang-Petersen O. 1980. Calcium nutrition of apple trees. A review. Sci. Hort. 12: 1-9.

Yue n C.M.C. 1993. Calcium and fruit storage potential. Postharvest Handling and Tropical Fruits. Proccedins of International Conference, Chiang Mai, Thailand, pp: 218-227.

\section{Wpływ liczby oprysków chlorkiem wapnia na jakość jabłek odmiany Jonagold}

\section{Streszczenie}

Celem doświadczenia było zbadanie wpływu liczby opryskiwań chlorkiem wapnia $\left(\mathrm{CaCl}_{2}\right)$ na jakość jabłek (Malus domestica Bokh.) odmiany Jonagold. Doświadczenie przeprowadzono w latach 1996-1998 w Sadzie Doświadczalnym Instytutu Sadownictwa i Kwiaciarstwa w Skierniewicach. Jabłonie okulizowane były na podkładce M26 i posadzone w 1992 roku w roztawie 4 × 2 m na glebie lekkiej o wysokiej zawartości przyswajalnego fosforu, potasu i magnezu. W doświadczeniu zastosowano cztery kombinacje: (i) trzy opryskiwania $\mathrm{CaCl}_{2}$ zastosowane 2, 10 i 18 tygodni po kwitnieniu, (ii) sześć opryskiwań $\mathrm{CaCl}_{2}$ zastosowane 2, 6, 10, 14, 16 i 18 tygodni po kwitnieniu, (iii)

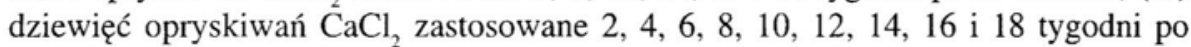
kwitnieniu, (iv) kontrola - drzewa nieopryskiwane $\mathrm{CaCl}_{2}$.

Wyniki badań wykazały, że koncentracja wapnia w jabłkach odmiany Jonagold wzrastała wraz z liczbą opryskiwań $\mathrm{CaCl}_{2}$ w sezonie wegetacyjnym. Jabłka dziewięciokrotnie opryskiwanie $\mathrm{CaCl}_{2}$ były mniejsze, mniej dojrzałe w momencie ich zbioru oraz po przechowywaniu, miały niższą zawartość kwasów i ekstraktu po przechowywaniu oraz były mniej wrażliwe na gorzką plamistość podskórną, rozpad wewnętrzny oraz 
gorzką zgniliznę w porównaniu do owoców z pozostałych kombinacji. Jednakże wpływ dziewięciokrotnego opryskiwania $\mathrm{CaCl}_{2}$ na powyższe parametry uzależniony był od sezonu wegetacyjnego. Tylko w jednym roku badań jabłka sześciokrotnie opryskiwane $\mathrm{CaCl}_{2}$ były jędrniejsze po przechowywaniu oraz mniej podatne na gorzką plamistość podskórną i rozpad wewnętrzny. Trzykrotne opryskiwanie $\mathrm{CaCl}_{2}$ tylko w jednym roku badań zmniejszyło występowanie gorzkiej plamistości podskórnej. 